\title{
Polysaccharide Hydrolase
}

National Cancer Institute

\section{Source}

National Cancer Institute. Polysaccharide Hydrolase. NCI Thesaurus. Code C99387.

An enzyme that hydrolyzes the breakdown of a polysaccharide to simple sugars. 